\title{
Nutrient dynamics in the Sundarbans mangrove estuarine system of Bangladesh under different weather and tidal cycles
}

Shak Md Bazlur Rahaman ${ }^{*}$, Lipton Sarder ${ }^{1}$, Md Sayadur Rahaman², Alokesh Kumar Ghosh', Sudhin Kumar Biswas ${ }^{1}$ SM Shahjahan Siraj ${ }^{1}$, Khandaker Anisul Huq ${ }^{1}$, Abul Farah Md Hasanuzzaman ${ }^{1}$ and Shikder Saiful Islam

\begin{abstract}
Introduction: Seasonal and tidal variations in nutrient concentration and water quality were investigated in the western Sundarbans of Bangladesh during the post-monsoon, winter and monsoon seasons during 2010-2011.

Methods: Water collected from the surface, middle and bottom layers at six locations of the Kholpetua-Arpangashia river system during high and low tides was analyzed for temperature, salinity, $\mathrm{pH}$, dissolved oxygen (DO), total dissolved solids (TDS), electrical conductivity (EC) and dissolved nutrients $\left(\mathrm{NO}_{3}-\mathrm{N}, \mathrm{PO}_{4}-\mathrm{P}, \mathrm{SO}_{4}\right.$ and $\mathrm{NH}_{3}-\mathrm{N}$ ).

Results: The study revealed that nutrient concentrations were influenced by seasonal changes. Mean nutrient levels during post-monsoon, winter and monsoon seasons, respectively, were in the following ranges: nitrate $(0.06-0.40$, 0.06-0.46 and 0.08-0.46 mg/L); phosphate (0.09-0.18, 0.05-0.42 and 0.10-0.16 mg/L); sulphate (58.71-86.14, 68.68-119.01 and $78.15-136.47 \mathrm{mg} / \mathrm{L})$ and ammonia $(0.02-0.08,0.02-0.04$ and $0.26-0.38 \mathrm{mg} / \mathrm{L})$. Increased levels of $\mathrm{PO}_{4}-\mathrm{P}$, $\mathrm{SO}_{4}$ and $\mathrm{NH}_{3}-\mathrm{N}$ and lower $\mathrm{DO}$ and salinity were recorded during the monsoon period. Most of the experimental sites showed higher $\mathrm{NO}_{3}-\mathrm{N}$ content during monsoon, whereas few elevated concentrations were observed during post-monsoon and winter periods. High and low tidal waters contained mean nutrient levels in the following ranges: nitrate $(0.05-0.46$ and $0.04-0.40 \mathrm{mg} / \mathrm{L})$; phosphate $(0.05-0.42$ and $0.07-0.18 \mathrm{mg} / \mathrm{L})$; sulphate (63.63-125.36 and 58.71-136.47 mg/L) and ammonia (0.02-0.38 and 0.02-0.37 mg/L) without following any distinct fluctuation patterns. The western part of the Sundarbans receives less freshwater input during the monsoon season than other areas of the ecosystem, which reduces the variability of nutrient levels and water quality components.
\end{abstract}

Conclusions: This study provides considerable advances in understanding the seasonality of nutrient distribution with possible tidal influence. The data generated from this study will guide continuing efforts to support a sound management for coastal mangrove ecosystems.

Keywords: Sundarbans; Monsoon; Post-monsoon; Nitrate; Phosphate; Sulphate; Ammonia; Aquatic ecosystem; Water quality; River

\footnotetext{
*Correspondence: riti_rahaman@yahoo.com

${ }^{1}$ Fisheries and Marine Resource Technology Discipline, Khulna University, Khulna 9208, Bangladesh

Full list of author information is available at the end of the article
} 


\section{Introduction}

The Sundarbans, the largest single tract of mangrove ecosystem in the world, is important from both ecological and economic perspectives. This pristine ecosystem was declared as Ramsar site no. 560 in 1992 and as a World Heritage site by UNESCO in 1997. Its ecological importance is associated with its rich biodiversity and the ecosystem's valuable services. The Sundarbans is home to an estimated 505 species of wildlife, including 355 species of birds, 49 species of mammals, 87 species of reptiles, 14 species of amphibians as well as emblematic species such as the Bengal tiger. Additionally, there are about 234 species of flora and more than 300 species of fish, including 237 species of finfish, 38 species of shellfish and 34 species of mollusks to enrich the ecosystem. Sundarbans acts as a buffer, protecting inhabitants of numerous human settlements against cyclones, rising sea levels and other hazardous weather events. In addition to its ecological functions, the Sundarbans also directly and indirectly supports the livelihoods of about 7 million people living in the vicinity of the forest.

The hydro-geochemical environment of the Sundarbans is highly dynamic in nature with numerous drainage channels and significant coastal processes. Being in the coastal waters, the abiotic and biotic resources of the Sundarbans are highly variable in response to the coastal dynamic processes. Inland waters from some major river systems flow through this intertidal mangrove forest, contributing to the deposition of substantial amounts of suspended matter, nutrients, heavy metals and other compounds. As a consequence of both natural and anthropogenic activities, the valuable ecosystem of Sundarbans has been subjected to considerable degradation. In addition human activities such as resource collection, fishing, shrimp farming, agriculture, and tourism, also interfere the dynamic coastal ecosystem.

Saltwater and freshwater meet in the rivers in the Sundarbans. Thus, it is a region of transition between the freshwater of the rivers originating from the Ganges and the saline water of the Bay of Bengal. Rupsha, Passur, Shibsa, Bhola, Baleswar, Arpangashia, Kholpetua, Malancha and other rivers open into the Bay of Bengal through the Sundarbans Reserve Forest and carry large amounts of nutrients that vary with tides and seasons, affecting the productivity in the area. These regions also play an important role in processing nutrients exchanged between land and sea (Eyre and Twigg 1997). Globally, estuarine nutrient loads have steadily increased in recent decades coincident with rises in the human population and industry. Such increases may boost primary production and provide either an additional sink and/or source for carbon as well as for phosphorus, nitrate and sulphate in coastal waters. The role of estuarine processes in modifying the chemistry of the materials accumulating and passing through this interface has so far been little studied. Coonley et al. (1971), Sholkovitz (1976) and Gobeil et al. (1981) studied geochemical processes, such as precipitation and flocculation of the dissolved and colloidal substances, while Yeats and Bewers (1982) investigated desorption-adsorption phenomena, chemical diagnosis and exchange with the bottom sediments within the mixing zone.

Nutrients in water play an important role in the lives of aquatic organisms including fish. Water nitrogen is found both as inorganic and organic species and in dissolved and particulate forms. Inorganic nitrogen exists both as oxidized species [e.g., nitrate $\left(\mathrm{NO}_{3}^{-}\right)$and nitrite $\left.\left(\mathrm{NO}_{2}^{-}\right)\right]$and reduced species [e.g., ammonia $\left(\mathrm{NH}_{4}^{+}+\mathrm{NH}_{3}\right)$ and nitrogen gas $\left(\mathrm{N}_{2}\right)$ ]. Water $\mathrm{pH}$ regulates the occurrence of different forms of ammonia. Phosphorus is found in water bodies in dissolved and particulate forms. Dissolved phosphorus is readily available for plants and consists of inorganic orthophosphate (e.g., $\mathrm{H}_{2} \mathrm{PO}_{4}^{-}, \mathrm{HPO}_{4}^{2-}, \mathrm{PO}_{4}^{3-}$ ) and organic phosphoruscontaining compounds (DOP). The particulate phosphorus pool consists of plants and animals and their remains, phosphorus in minerals (e.g., fluorapatite) and phosphate adsorbed onto iron oxyhydroxides on mineral surfaces. All aquatic organisms including fish depend directly on nutrients for their survival, growth and reproduction. Some nutrient levels are related to the chlorophyll availability of the water body, which means the availability of phytoplankton in the water. Thus nutrient availability is directly related to the productivity of the water body. A shortage of nutrients causes the water body to be unproductive. An excess of nutrients causes eutrophication by algal bloom and makes the water toxic. So, nutrient concentration must be within an acceptable limit for a good aquatic environment and for better production of aquatic organisms including fish.

Despite the importance of understanding the water quality of such intertidal mangrove ecosystems, very few attempts have been made to investigate the issues. The present study has been undertaken to quantify some major nutrients at different depths and locations and to calculate tidal and seasonal fluctuations in nutrient concentrations from upstream to downstream in the Kholpetua-Arpangashia river system (RS) of the Sundarbans mangrove forest. The study will provide an ecological baseline for the World Heritage site and serves as a basis for establishing monitoring programs and predicting changes at sites with high hydrological variations.

\section{Methods}

\section{Study area}

The western Sundarbans, where Kholpetua-Arpangashia RS is located, was selected for the present study. Field observation was conducted at six stations, namely Pashurtala, Pashurtala Canal, Kalagachhi, Kalagachhi Canal, Nildumur 
and Arpangashia, which are situated at different locations of the RS (Figure 1). The geographical locations of the study sites and their depths at high and low tides are shown in Table 1 . The sampled sites are characterized by semidiurnal tides and strong currents. Comprehensive field measurements were made under different climatic conditions-post-monsoon (October 2010), winter (February 2011) and monsoon (August 2011) - and at different tidal cycles.

\section{Sampling and experimental set-up}

Seasonal and tidal monitoring of physicochemical parameters and major nutrients was undertaken for the surface, middle and bottom layers of each water body. For in-situ measurement and laboratory analysis, water samples were collected from the three discrete layers of the selected measuring stations during post-monsoon, winter and monsoon seasons under both high and low tide conditions. Ruttner Water Sampler and DO Sampler were deployed with marked ropes to collect samples from the required depths. During in-situ measurement, water salinity was measured by refractometer (ATAGO S/Mill- ${ }_{E}$ ), while temperature and $\mathrm{pH}$ were measured by digital thermometer with stainless steel sensor probe and HANNA Microprocessor $\mathrm{pH}$ meter (HI, pH 211), respectively. Winkler's method (APHA 1992) was followed during measurement of dissolved oxygen (DO), and total dissolved solids (TDS) and conductivity were identified with the help of a multi-parameter water test kit.
For laboratory analysis, water samples were taken into $250 \mathrm{ml}$ plastic bottles, immediately preserved in an icebox, and later carried to the laboratory for nutrient analysis. Nutrient parameters were analyzed in the water chemistry laboratory of the Fisheries and Marine Resource Technology Discipline, Khulna University. During analysis of nutrient concentration, the ascorbic acid method was used for phosphate and sulphate, and Nesslerization and phenol disulphonic acid methods were used for ammonia and nitrate, respectively. A highly equipped spectrophotometer was used for estimating the concentration of water nutrients.

\section{Results and discussion}

\section{Physical characteristics of the study area}

The Kholpetua-Arpangashia is the widest RS in the western part of the Sundarbans mangrove forest. The RS is connected with the Malancha and Baleswar Rivers, and with many canals and creeks inside the Sundarbans. Arpangashia and Malancha are connected to River Bhairab by the Kobadak River and used to receive freshwater flow from the Ganges through the Gorai River. The RS receives freshwater mainly from the runoff and the polder areas. Water salinity in the Kholpetua-Arpangashia RS is normally higher than in the other regions of the mangrove forest. The Sundarbans intertidal mangrove forest lies in the vast delta on the Bay of Bengal formed by the superconfluence of the Padma, Brahmaputra and Meghna rivers across southern Bangladesh. The forest covers nearly $10,000 \mathrm{~km}^{2}$ of which about $6,000 \mathrm{~km}^{2}$ are in Bangladesh. The Sundarbans is

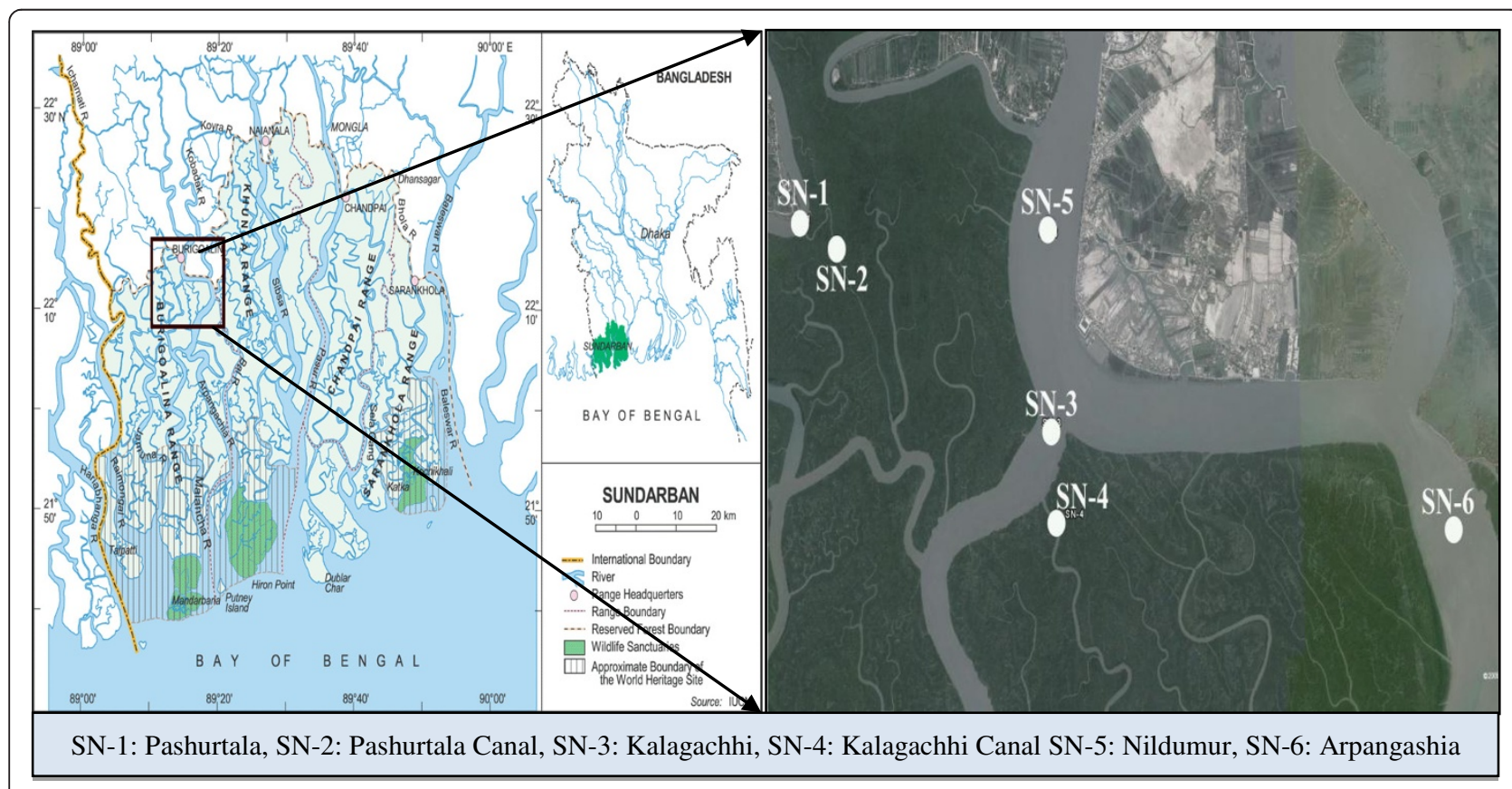

Figure 1 Map of the Sundarbans (left) and location of the study points in the Kholpetua-Arpangashia river system (right). 
Table 1 Geographical location of the study points and their water depths at high and low tides during sampling

\begin{tabular}{lllcc}
\hline $\begin{array}{l}\text { Sampling } \\
\text { station }\end{array}$ & Longitude & Latitude & \multicolumn{2}{c}{ Water depth $(\mathbf{m})$} \\
\cline { 4 - 5 } & & & High tide & Low tide \\
\hline Pashurtala & $89^{\circ} 11^{\prime} 59.18^{\prime \prime} \mathrm{E}$ & $22^{\circ} 14^{\prime} 8.10^{\prime \prime} \mathrm{N}$ & 15.9 & 12.5 \\
Pashurtala Canal & $89^{\circ} 12^{\prime} 21.30^{\prime \prime} \mathrm{E}$ & $2^{\circ} 14^{\prime} 1.45^{\prime \prime} \mathrm{N}$ & 3.7 & 1.6 \\
Kalagachhi & $89^{\circ} 14^{\prime} 37.35^{\prime \prime} \mathrm{E}$ & $22^{\circ} 12^{\prime} 56.10^{\prime \prime} \mathrm{N}$ & 11.4 & 6.6 \\
Kalagachhi Canal & $89^{\circ} 14^{\prime} 42.12^{\prime \prime} \mathrm{E}$ & $22^{\circ} 12^{\prime} 21.34^{\prime \prime} \mathrm{N}$ & 5.2 & 3.2 \\
Nildumur & $89^{\circ} 14^{\prime} 32.17^{\prime \prime} \mathrm{E}$ & $22^{\circ} 14^{\prime} 13.38^{\prime \prime} \mathrm{N}$ & 10.9 & 10.1 \\
Arpangashia & $89^{\circ} 18^{\prime} 51.14^{\prime \prime} \mathrm{E}$ & $22^{\circ} 12^{\prime} 16.50^{\prime \prime} \mathrm{N}$ & 11.6 & 9.8 \\
\hline
\end{tabular}

estimated to be about $4,110 \mathrm{~km}^{2}$, of which about 1,700 $\mathrm{km}^{2}$ is occupied by water bodies in the forms of rivers, canals and creeks of widths varying from a few meters to several kilometers. The coast of the Sundarbans is crisscrossed by a complex estuarine network created by many rivers which open into the Bay of Bengal through the Sundarbans Reserve Forest. The Bangladesh part of the Sundarbans spreads over the districts of Khulna, Bagerhat and Satkhira. It covers almost $62 \%$ of their total land cover. Geographically it lies between latitudes $21^{\circ} 31^{\prime} \mathrm{N}$ and $22^{\circ} 30^{\prime} \mathrm{N}$ and between longitudes $89^{\circ} 18^{\prime} \mathrm{E}$ and $90^{\circ} 18^{\prime} \mathrm{E}$ (Figure 1) (Katebi 2001).

Water depth at the RS inside the Sundarbans is highly dependent on the tidal oscillation at the coast and to a lesser extent on the magnitude of freshwater inflows from upstream. During field observation, water depths at the sampling stations were found to vary from 1.6 to $12.5 \mathrm{~m}$ and 3.7 to $15.9 \mathrm{~m}$ during falling and rising tides, respectively. Tides of the RS are semidiurnal with two high water and two low water levels per day. During rising tides, more saline offshore water flows toward the upstream, whereas during falling tide conditions, inland freshwater and less saline waters from the upstream area flow toward the downstream region.
The variations in water levels and tidal amplitudes experienced at the coast are also propagated inland during each tidal cycle. Tidal range of the northern fringe of the forest is higher than the southern part. The lowest recorded tidal range was $2.74 \mathrm{~m}$ and the highest range was $5.12 \mathrm{~m}$ (IWM 2003). During spring tide in the monsoon season, the forest area is inundated for a maximum of 3-4 h. The pre-monsoon season showed comparatively higher inundation than the dry season, although the entire area of the Sundarbans mangrove forest does not get flooded in these periods. The average current velocities varied from $10-20 \mathrm{~cm} / \mathrm{s}$. Both deposition and erosion occur at the end of the monsoon season. The maximum net deposition and erosion at the end of monsoon were found to be around 50 and $19 \mathrm{~mm}$, respectively (IWM 2003).

\section{Physicochemical parameters \\ Temperature}

Mean water temperature at the study points ranged from 21.40 to $30.67^{\circ} \mathrm{C}$ with an average of $27.17^{\circ} \mathrm{C}$ over the three different sampling seasons and two tidal cycles (Figure 2 and Table 2). During the post-monsoon, winter and monsoon seasons, mean temperatures were recorded in the range of $28.43-29.27^{\circ} \mathrm{C}, 21.40-23.47^{\circ} \mathrm{C}$ and $29.13-30.67^{\circ} \mathrm{C}$, respectively, with water temperatures decreasing in dry winter months following the post-monsoon season and then increasing considerably during the monsoon period. The estuarine stretch did not exhibit significant variation in water temperature with the tidal periods. Spatial variation in water temperature was also not so significant due to high specific heat of the aquatic phase which enables water to resist much fluctuation of temperature. Highest and lowest water temperatures in the Sundarbans RS were recorded by Hoq et al. (2002) during monsoon and

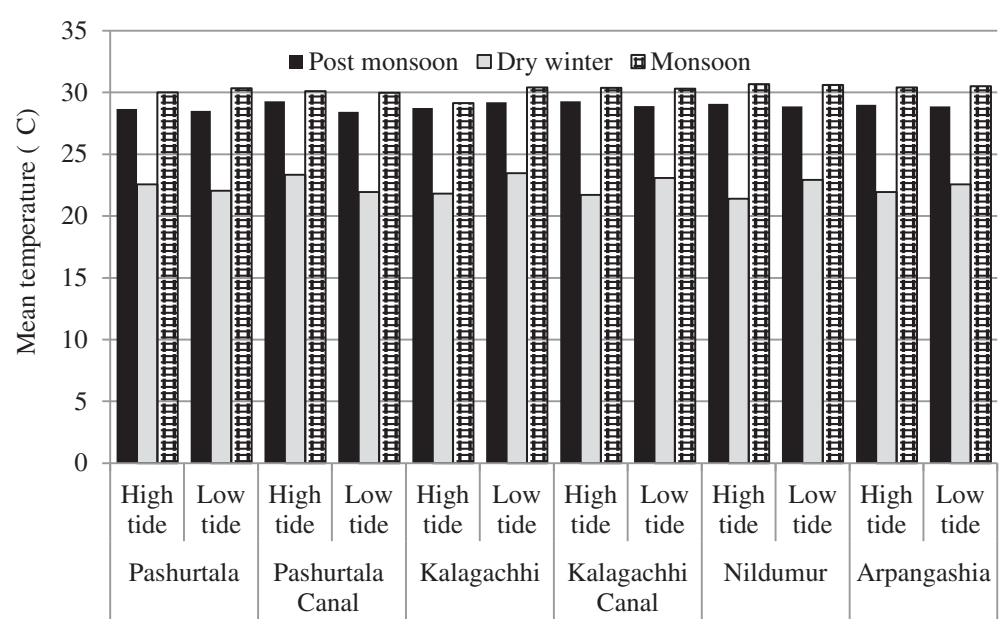

Figure 2 Temperature distributions in the study area under different seasons and tidal cycles. 
Table 2 Calculated mean values of temperature, pH, salinity and dissolved oxygen (DO) recorded at the surface, middle and bottom water layers of the study sites during high and low tides

\begin{tabular}{llllll}
\hline Stations & Sampling season & Temperature $\left({ }^{\circ} \mathbf{C}\right)$ & pH & Salinity (\%o) & DO (mg/L) \\
\hline Pashurtala & Post-monsoon & $28.58 \pm 0.263$ & $7.33 \pm 0.186$ & $13.16 \pm 0.983$ & $5.23 \pm 1.123$ \\
& Dry winter & $22.30 \pm 0.603$ & $7.53 \pm 0.299$ & $21.16 \pm 0.983$ & $5.06 \pm 0.355$ \\
Pashurtala Canal & Monsoon & $30.17 \pm 0.250$ & $7.40 \pm 0.378$ & $10.25 \pm 0.418$ & $4.35 \pm 0.413$ \\
& Post-monsoon & $28.85 \pm 0.637$ & $7.55 \pm 0.104$ & $13.16 \pm 0.983$ & $5.66 \pm 0.621$ \\
& Dry winter & $22.63 \pm 0.880$ & $7.66 \pm 0.130$ & $21.16 \pm 0.752$ & $5.23 \pm 0.403$ \\
Kalagachhi & Monsoon & $30.03 \pm 0.361$ & $7.58 \pm 0.123$ & $11 \pm 0.547$ & $3.96 \pm 0.081$ \\
& Post-monsoon & $28.96 \pm 0.45$ & $7.58 \pm 0.116$ & $12.5 \pm 1.64$ & $5.33 \pm 0.989$ \\
& Dry winter & $22.63 \pm 0.928$ & $7.73 \pm 0.038$ & $22.16 \pm 0.752$ & $5.48 \pm 0.856$ \\
Kalagachhi Canal & Monsoon & $29.76 \pm 1.36$ & $7.65 \pm 0.047$ & $9.33 \pm 0.516$ & $3.93 \pm 0.121$ \\
& Post-monsoon & $29.08 \pm 0.318$ & $7.51 \pm 0.040$ & $11.5 \pm 1.643$ & $6.16 \pm 1.23$ \\
Nildumur & Dry winter & $22.38 \pm 0.767$ & $7.67 \pm 0.265$ & $22.66 \pm 0.516$ & $4.9 \pm 0.593$ \\
& Monsoon & $30.33 \pm 0.081$ & $7.64 \pm 0.087$ & $9.66 \pm 0.408$ & $3.98 \pm 0.116$ \\
& Post-monsoon & $28.96 \pm 0.508$ & $7.56 \pm 0.121$ & $11.83 \pm 2.041$ & $6.23 \pm 0.882$ \\
Arpangashia & Dry winter & $22.16 \pm 0.871$ & $7.67 \pm 0.098$ & $22.83 \pm 0.258$ & $4.98 \pm 0.098$ \\
& Monsoon & $30.63 \pm 0.332$ & $7.64 \pm 0.111$ & $9.41 \pm 0.376$ & $4.18 \pm 0.098$ \\
& Post-monsoon & $28.93 \pm 0.163$ & $7.51 \pm 0.147$ & $11.33 \pm 0.516$ & $5.46 \pm 0.771$ \\
& Dry winter & $22.25 \pm 0.413$ & $7.73 \pm 0.176$ & $23.33 \pm 0.816$ & $5.41 \pm 0.560$ \\
& Monsoon & $30.45 \pm 0.187$ & $7.79 \pm 0.103$ & $9 \pm 0.632$ & $4.33 \pm 0.186$ \\
\hline
\end{tabular}

winter seasons, respectively. Tait (1981) and Pliński and Jóźwiak (1999) concluded that nutrient concentrations (nitrate, phosphate and silicate) of the aquatic system may be influenced when temperatures rise as temperature affects the photosynthesis rate.

\section{pH}

Water $\mathrm{pH}$ was found to vary at the study sites between 7.08 and 7.87 with an average value of 7.60. Higher $\mathrm{pH}$ values were mostly recorded during winter when the tide was rising, whereas during post-monsoon and monsoon seasons, the $\mathrm{pH}$ of most of the stations was a bit higher at low tide than at high tide (Figure 3 and Table 2). Factors such as photosynthesis, which removes $\mathrm{CO}_{2}$ through bicarbonate degradation; freshwater input, which causes dilution of seawater and reduction in salinity and temperature; and decomposition of organic matter, can contribute to the fluctuations in $\mathrm{pH}$ in the study area. According to Hoq et al. (2006), the pH of Sundarbans river water is slightly alkaline and remains neutral to alkaline (7.4-8.1) throughout the year. Adedokun et al. (2008) observed higher $\mathrm{pH}$ in the RS

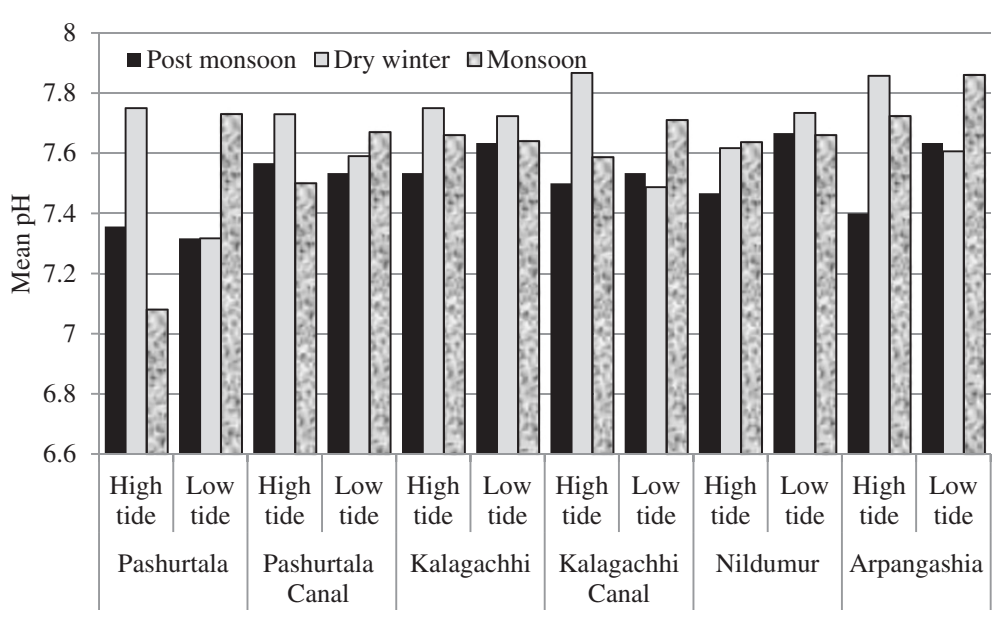

Figure 3 Seasonal and tidal variations in water $\mathrm{pH}$ at the experimental sites. 
of Ibadan Metropolis, Nigeria, during rainy season than during dry season.

\section{Salinity}

Water salinity in the Sundarbans RS is highly dependent on the freshwater input coming from the upstream areas and the nature of tide. Salinity near the coast and within the forest varies over a number of different timescales. Daily peak salinity at the coast generally coincides with the arrival of high tide, whereas the daily range of the salinity level varies with the season. Seasonal fluctuation in salinity is related to the changes in freshwater flow from upstream rivers. Salinity at the KholpetuaArpangashia RS, which is along the western boundary areas of the Sundarbans, did not fall below $8 \%$ even during the monsoon period, when significant precipitation occurs. Overall, mean water salinity ranged between 10 and $14 \%$, 20.67 and $22.83 \%$ and 8.67 and $11.33 \%$ during post-monsoon, winter and monsoon seasons, respectively (Figure 4 and Table 2). Following the post-monsoon period, salinity steadily increased to a maximum of nearly $23 \%$ during the dry winter season and then significantly dropped during the monsoon period. It has already been reported that water salinity increases from the upstream to the downstream zone. During high tide, water from the Bay of Bengal enters the present estuarine zone contributing to the increasing salinity. However, during low tide, the effect of freshwater discharge from the upstream rivers lowers the salinity of the study area. Such variation in salinity with tide was also documented in several earlier studies (NEERI 1976; Mitra et al. 2011; Mukhopadhyay et al. 2006).

Salinity along the eastern boundary of the mangrove forest is influenced by the Baleswar River; salinity in this part is almost zero throughout the monsoon period. The northern and north central parts of the Sundarbans are influenced by the freshwater flow of the Passur River, which originates from the Gorai River. Salinity in the southern part of the Bay remains below 5\% during the monsoon period and starts to increase at a steady rate up to about $15 \%$ during the dry season (IWM 2003). Salinity in the western region remains comparatively higher than the other parts of the Sundarbans even during monsoon season due to less freshwater influx from inland sources. Hoq et al. (2006) observed that the water salinity of the Sundarbans mangrove forest steadily increases to its maximum in March following the monsoon period and starts declining from June to a minimum in the monsoon months from July to September.

\section{Dissolved oxygen}

Mean DO at the study locations ranged from 3.90 to $7.03 \mathrm{mg} / \mathrm{L}$ with an average of $5.00 \mathrm{mg} / \mathrm{L}$ (Figure 5 and Table 2). Higher concentrations of DO were found in post-monsoon (4.37-7.03 $\mathrm{mg} / \mathrm{L})$ and dry winter (4.37$6.23 \mathrm{mg} / \mathrm{L}$ ) seasons, whereas the monsoon period showed a lower DO (3.90-4.63 $\mathrm{mg} / \mathrm{L})$ in the river water of the Sundarbans. Rahman et al. (2013) conducted an investigation of the water quality in the Rupsha-Passur RS of the Sundarbans forest and recorded the highest DO concentration $(6.0-7.33 \mathrm{mg} / \mathrm{L})$ during winter; nonetheless, the highest biochemical oxygen demand (BOD) (20.2-28.0 $\mathrm{mg} / \mathrm{L})$ was obtained in summer season. Hoq et al. (2002) recorded the highest DO of $7.1 \mathrm{mg} / \mathrm{L}$ in the monsoon, whereas the pre-monsoon period showed the lowest DO $(4.9 \mathrm{mg} / \mathrm{L})$ concentration. The higher values of DO at the upstream stations during the monsoon may be due to DO-enriched inland freshwater input through the river in the eastern part of the Sundarbans. Nair (1985) reported that the DO level can be increased through freshwater input, while Weiss (1970) mentioned the impacts of temperature and salinity on DO concentration. Badran (2001) concluded that a

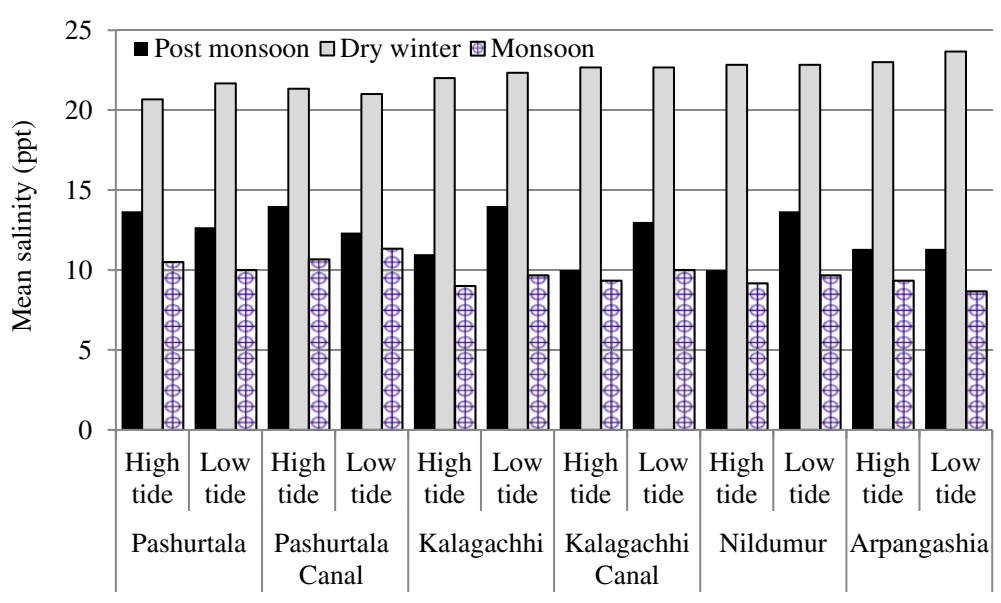

Figure 4 Variations in salinity at the study sites during high and low tide in three different seasons. 


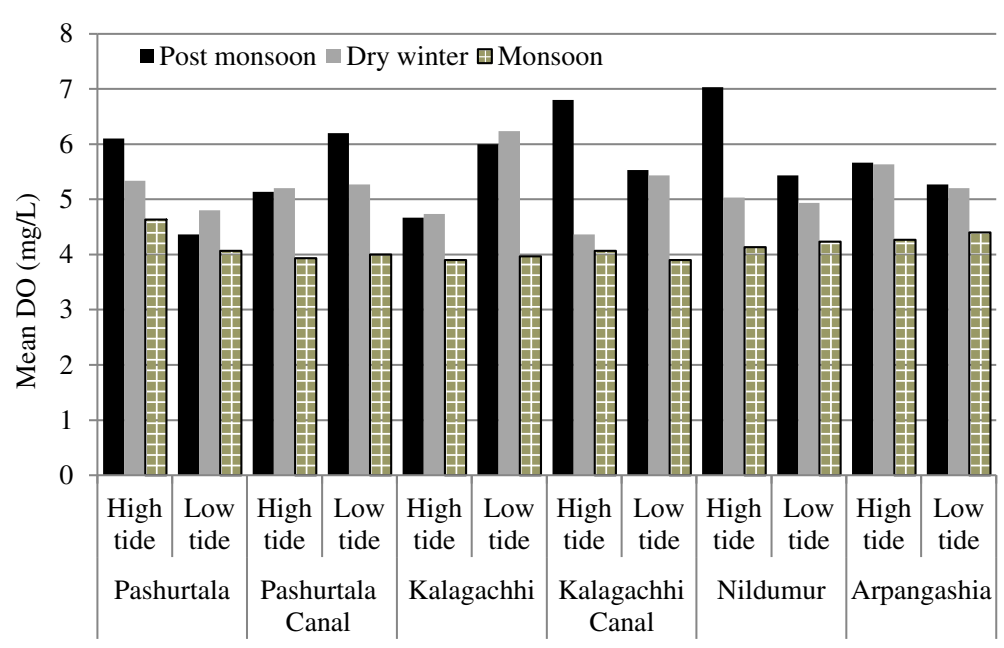

Figure 5 Mean DO concentrations at the sampling points during high and low tide in different seasons.

relatively lower DO level was due to high temperature and salinity. DO concentrations will also depend on the photosynthetic rate and therefore on nutrient concentrations. The present study shows that the DO level falls in the monsoon season. In contrast, most of the nutrient constituents were found to increase (Figures 6, 7, 8 and 9) in the monsoon period. Thus DO and nutrient concentrations showed an almost inverse relationship in the western part of the mangrove forest. In comparison with other parts of the Sundarbans, the western part is least affected by the inland freshwater influx, which might contribute to this different scenario of DO level in the monsoon period.

\section{Electrical conductivity and total dissolved solids}

Mean electrical conductivity (EC) ranged from 16.23 to $33.97 \mathrm{mS} / \mathrm{cm}$ with an average of $26.15 \mathrm{mS} / \mathrm{cm}$. Postmonsoon, winter and monsoon water showed EC of $16.23-20.10,25.83-28.53$ and $31.53-33.97 \mathrm{mS} / \mathrm{cm}$, respectively. Following the post-monsoon season, the conductivity level gradually increased through the winter and monsoon seasons. Total dissolved solids (TDS) recorded at the study locations under different tidal and weather conditions ranged between 902.67 and 2,263.33 ppm with an average of $1,733.52 \mathrm{ppm}$. Mean TDS values ranged from 902.67 to $1,319.00 \mathrm{ppm}, 1,716.67$ to $1,870.00 \mathrm{ppm}$ and $2,100.00$ to $2,263.33 \mathrm{ppm}$ during postmonsoon, winter and monsoon seasons, respectively. TDS and conductivity were both highest during the monsoon period, whereas the lowest levels occurred post-monsoon, which indicated a more-or-less positive relationship with nutrient loads in the study area (Figures 6, 7, 8 and 9). In contrast to the present study, Hoq et al. (2006) observed TDS values to be lower during the monsoon, with a higher range of TDS occurring during the pre-monsoon period in the eastern part of the forest. The authors recorded low TDS in the Passur and Shibsa rivers where the observation was conducted. However, Adedokun et al. (2008), who observed seasonal limnological variations and nutrient loads of the RS in Ibadan Metropolis, Nigeria, recorded higher TDS during the rainy season than the dry season.

\section{Concentrations of nutrients \\ Nitrate}

In Kholpetua-Arpangashia RS, mean $\mathrm{NO}_{3}-\mathrm{N}$ concentrations were found to vary from 0.04 to $0.46 \mathrm{mg} / \mathrm{L}$ with an average of $0.15 \mathrm{mg} / \mathrm{L}$ over the three sampling seasons (Figure 6 and Table 3). The highest mean values were recorded in Pashurtala at high tide and Kolagachi at low tide during the dry winter and monsoon periods, respectively, whereas Nildumur showed the lowest nitrate concentration at low tide during the dry season. The average $\mathrm{NO}_{3}-\mathrm{N}$ concentration of $0.15 \mathrm{mg} / \mathrm{L}$ is an indication of little or no human intervention in the river system. Kumar et al. (2009), who made field measurements in an estuarine zone, pointed out that nitrate concentration was higher during monsoon due to freshwater influx. Recorded nitrate content in Sundarbans RS was comparatively lower than Wahid et al. (2007), who observed an average concentration of $0.461 \mathrm{mg} / \mathrm{L}$. Greater concentration of atmospheric $\mathrm{N}_{2}$ and its continuous mixing in river water through air and surface water interactions might be the reason for the irregular fluctuation in $\mathrm{NO}_{3}-\mathrm{N}$ throughout the sampling periods and tide cycles in the study area.

\section{Phosphate}

Mean phosphate concentrations as $\mathrm{PO}_{4}-\mathrm{P}$ measured at different tidal cycles over three sampling seasons were generally low, ranging from 0.05 to $0.42 \mathrm{mg} / \mathrm{L}$ with an average of $0.12 \mathrm{mg} / \mathrm{L}$ (Figure 7 and Table 3). Average 


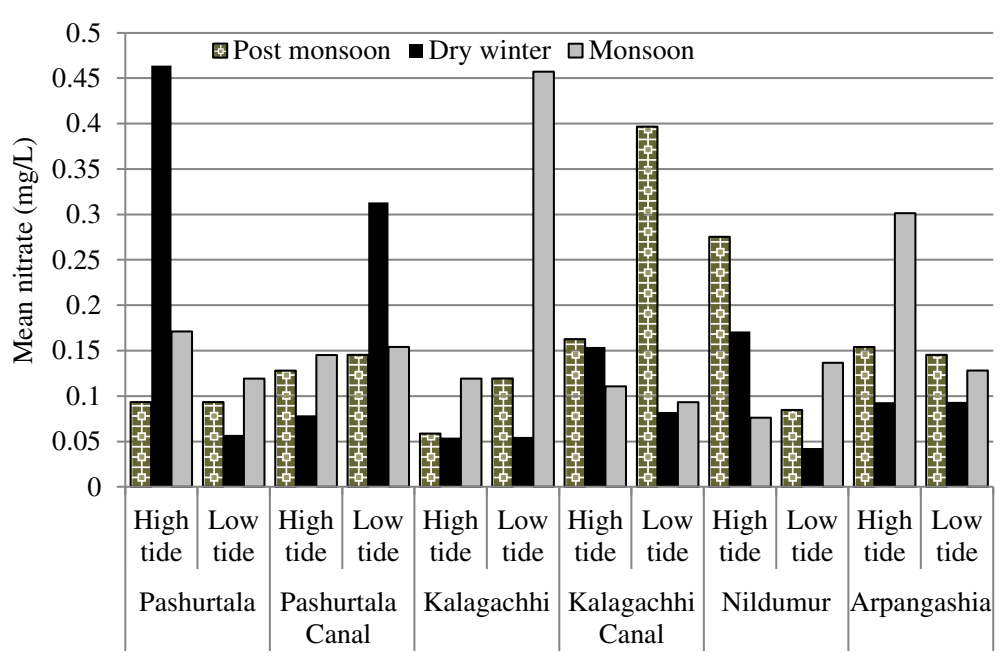

Figure 6 Mean nitrate concentrations at the sampling points during high and low tide in different seasons.

phosphate levels were slightly higher at most study locations during monsoon than they were during the post-monsoon and dry seasons. Kumar et al. (2009) and Adedokun et al. (2008) observed higher phosphate content during monsoon. In our study, the maximum concentration was recorded during the dry season at Nildumur and the lowest was measured at Pasurtala under the same weather conditions. Highest and lowest phosphate levels were found when the tide was rising at the experimental sites. The average $\mathrm{PO}_{4}-\mathrm{P}$ concentration, $0.12 \mathrm{mg} / \mathrm{L}$, was lower than the acceptable limit set by the Environmental Quality Standard (EQS) of Bangladesh (Table 4). The Department of Environment (DOE), Bangladesh defines the EQS of $\mathrm{PO}_{4}$ as between 6 and $10 \mathrm{mg} / \mathrm{L}$ (DOE 1991). This range was converted to values for $\mathrm{PO}_{4}-\mathrm{P}$ of $0.2-0.3 \mathrm{mg} / \mathrm{L}$ for comparison purposes. Recorded phosphate values are more-or-less similar to the findings of Wahid et al. (2007), where the average figure was $0.115 \mathrm{mg} / \mathrm{L}$. The Institute of Water Modeling (2003) found relatively low concentrations of $0.009-0.582 \mathrm{mg} / \mathrm{L}$ with an average of $0.115 \mathrm{mg} / \mathrm{L}$. It is assumed that limited inland freshwater input in the western Sundarbans RS as well as a cut off from the Ganges, the largest source of freshwater flow in the country, may contribute to the lower concentration of phosphate in the study area.

\section{Sulphate}

Figure 8 shows mean sulphate values for high and low tides at the different experimental sites during post-

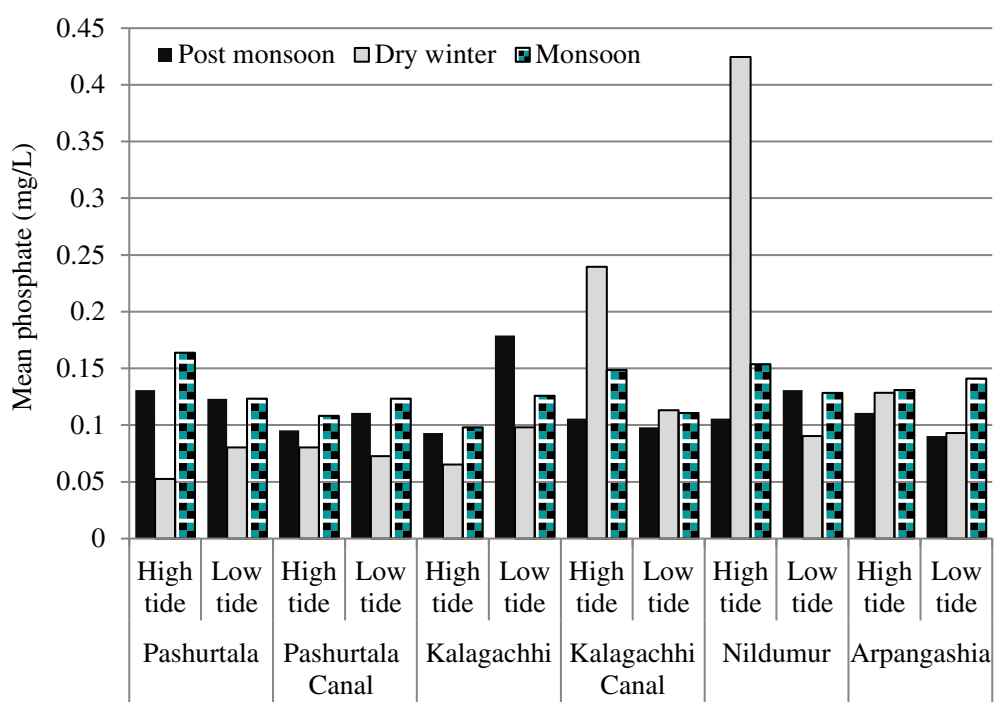

Figure 7 Mean phosphate concentrations at the sampling points at high and low tides in different seasons. 


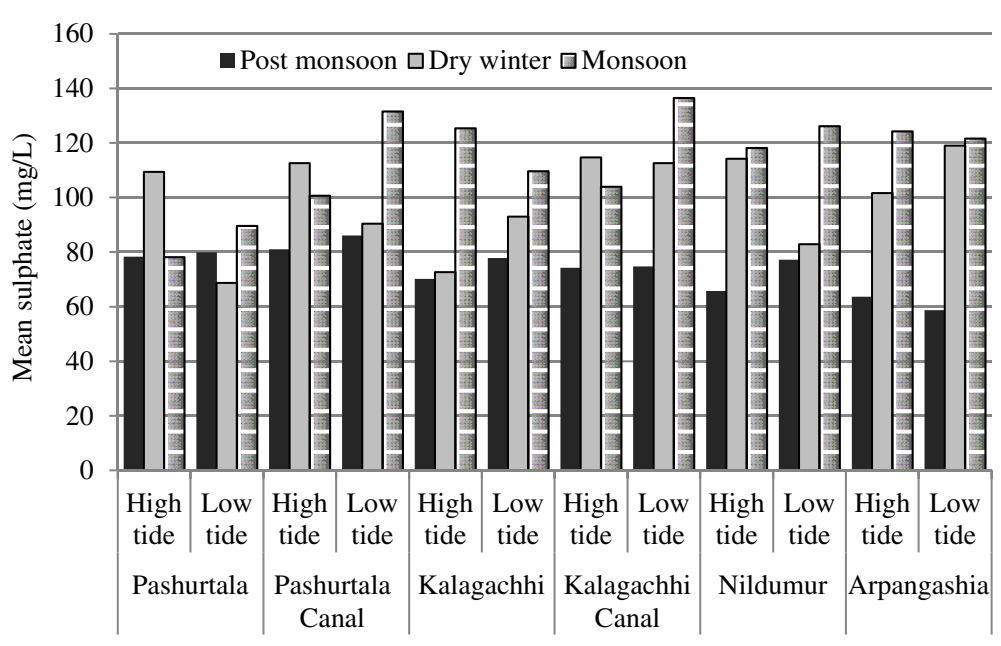

Figure 8 Mean sulphate concentrations at the sampling sites at high and low tides in different seasons.

monsoon, winter and monsoon seasons. $\mathrm{SO}_{4}$ concentrations were found to vary between 58.71 and $136.47 \mathrm{mg} / \mathrm{L}$ with an average of $95.69 \mathrm{mg} / \mathrm{L}$. Arpangashia station showed the lowest concentration of sulphate at low tide during the post-monsoon season, whereas the highest amount was detected at Kalagachhi Canal during the monsoon period, also during low tide. The average $\mathrm{SO}_{4}$ value $(95.69 \mathrm{mg} / \mathrm{L})$ indicates sufficient $\mathrm{SO}_{4}$ concentration in the mangrove water body. The reason the highest levels of $\mathrm{SO}_{4}$ were found during the monsoon period can be the huge runoff from the river and from surrounding agricultural areas (e.g., fertilizers) and wastewater (including sewage), eroded soils and aquaculture activities. Seawater input along with resuspension mixing of decayed organic matter and oxidation of buried biogenic materials result in enhanced sulphate levels in mangrove waters (Ramanathan et al. 1993). An elevated amount of sulphate was recorded during monsoon periods by some other studies conducted in the estuarine RS (Kumar et al. 2009; Adedokun et al. 2008).

\section{Ammonia}

The study sites showed mean concentrations of $\mathrm{NH}_{3}-\mathrm{N}$ between 0.02 and $0.38 \mathrm{mg} / \mathrm{L}$ with an average of $0.14 \mathrm{mg} / \mathrm{L}$ over several tidal cycles and three different seasons (Figure 9 and Table 3). Most of the observation sites showed significantly higher concentrations $(0.26$ and $0.38 \mathrm{mg} / \mathrm{L}$ ) of ammonia during monsoon at both high and low tides. In contrast to this, relatively lower amounts $(0.02$ and $0.08 \mathrm{mg} / \mathrm{L})$ of ammonia were detected at all sampling sites during post-monsoon and winter periods. Lower concentrations (an average of $0.14 \mathrm{mg} / \mathrm{L}$ ) of nonionized ammonia $\left(\mathrm{NH}_{3}-\mathrm{N}\right)$ indicate the presence of better quality water in the western RS with respect to ammoniacal nitrogen inside the Sundarbans as higher concentration causes toxicity in river water. River runoff from

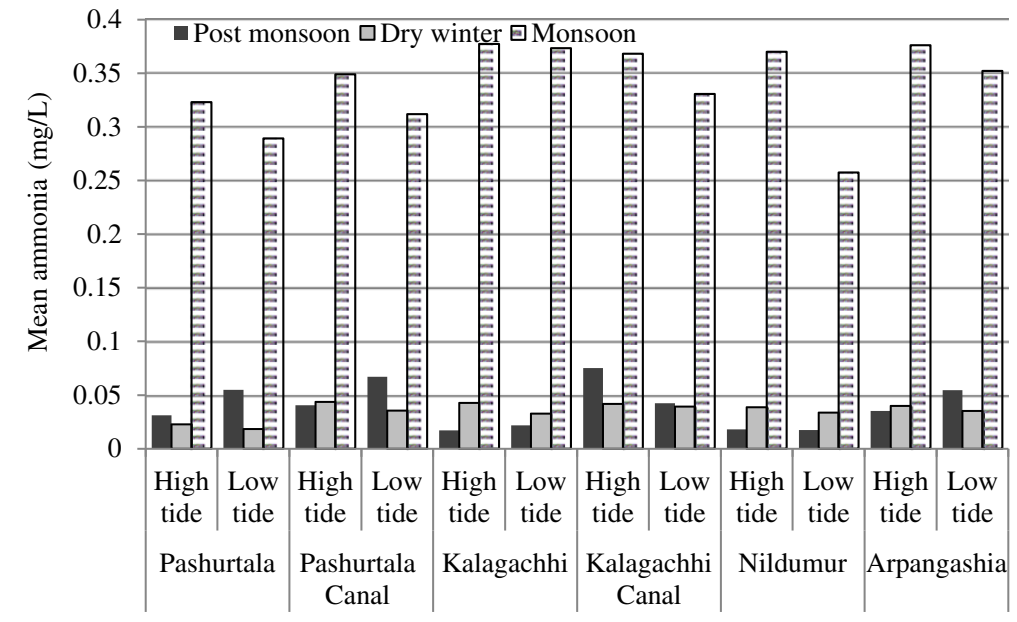

Figure 9 Mean ammonia concentrations at the sampling sites during high and low tide in different seasons. 
Table 3 Mean ammonia, nitrate, phosphate and sulphate content at the study points during field measurement

\begin{tabular}{|c|c|c|c|c|c|}
\hline \multirow[t]{2}{*}{ Stations } & \multirow[t]{2}{*}{ Seasons } & \multicolumn{4}{|c|}{ Concentrations of nutrients $(\mathrm{mg} / \mathrm{L})$} \\
\hline & & $\mathrm{NH}_{3}-\mathrm{N}$ & $\mathrm{NO}_{3}-\mathrm{N}$ & $\mathrm{PO}_{4}-\mathrm{P}$ & $\mathrm{SO}_{4}$ \\
\hline \multirow[t]{3}{*}{ Pashurtala } & Post-monsoon & $0.042 \pm 0.038$ & $0.093 \pm 0.067$ & $0.127 \pm 0.039$ & $79.09 \pm 2.18$ \\
\hline & Dry winter & $0.02 \pm 0.012$ & $0.260 \pm 0.462$ & $0.066 \pm 0.022$ & $89.031 \pm 32.14$ \\
\hline & Monsoon & $0.306 \pm 0.104$ & $0.145 \pm 0.051$ & $0.143 \pm 0.035$ & $83.86 \pm 10.55$ \\
\hline \multirow[t]{3}{*}{ Pashurtala Canal } & Post-monsoon & $0.053 \pm 0.055$ & $0.136 \pm 0.053$ & $0.103 \pm 0.018$ & $83.58 \pm 3.99$ \\
\hline & Dry winter & $0.039 \pm 0.004$ & $0.195 \pm 0.305$ & $0.076 \pm 0.054$ & $101.49 \pm 16.20$ \\
\hline & Monsoon & $0.330 \pm 0.049$ & $0.149 \pm 0.030$ & $0.115 \pm 0.052$ & $116.09 \pm 22.58$ \\
\hline \multirow[t]{3}{*}{ Kalagachhi } & Post-monsoon & $0.018 \pm 0.006$ & $0.089 \pm 0.074$ & $0.135 \pm 0.059$ & $74.04 \pm 5.33$ \\
\hline & Dry winter & $0.037 \pm 0.006$ & $0.054 \pm 0.014$ & $0.081 \pm 0.035$ & $82.78 \pm 20.35$ \\
\hline & Monsoon & $0.375 \pm 0.030$ & $0.288 \pm 0.471$ & $0.111 \pm 0.041$ & $117.50 \pm 11.19$ \\
\hline \multirow[t]{3}{*}{ Kalagachhi Canal } & Post-monsoon & $0.058 \pm 0.028$ & $0.279 \pm 0.391$ & $0.101 \pm 0.011$ & $74.53 \pm 1.69$ \\
\hline & Dry winter & $0.040 \pm 0.002$ & $0.118 \pm 0.068$ & $0.176 \pm 0.240$ & $113.63 \pm 2.85$ \\
\hline & Monsoon & $0.349 \pm 0.068$ & $0.102 \pm 0.043$ & $0.129 \pm 0.025$ & $120.20 \pm 18.76$ \\
\hline \multirow[t]{3}{*}{ Nildumur } & Post-monsoon & $0.017 \pm 0.007$ & $0.18 \pm 0.188$ & $0.118 \pm 0.029$ & $71.51 \pm 6.92$ \\
\hline & Dry winter & $0.036 \pm 0.004$ & $0.106 \pm 0.095$ & $0.257 \pm 0.441$ & $98.53 \pm 17.36$ \\
\hline & Monsoon & $0.313 \pm 0.076$ & $0.106 \pm 0.044$ & $0.140 \pm 0.028$ & $122.14 \pm 7.16$ \\
\hline \multirow[t]{3}{*}{ Arpangashia } & Post-monsoon & $0.044 \pm 0.045$ & $0.149 \pm 0.060$ & $0.100 \pm 0.017$ & $61.16 \pm 3.82$ \\
\hline & Dry winter & $0.037 \pm 0.003$ & $0.093 \pm 0.068$ & $0.110 \pm 0.053$ & $110.32 \pm 11.44$ \\
\hline & Monsoon & $0.364 \pm 0.049$ & $0.214 \pm 0.121$ & $0.135 \pm 0.022$ & $122.92 \pm 5.76$ \\
\hline
\end{tabular}

Mean values are calculated using data obtained from surface, middle and bottom layers of the water body at each station under both high and low tide conditions.

inland areas, which are characterized by diversified agricultural and aquaculture activities (both practices involve the application of fertilizers and other chemicals) as well as wastewater runoff and eroded soils may contribute to the higher concentrations of ammonia during monsoon. Wahid et al. (2007) mentioned an average ammonia concentration of $0.054 \mathrm{mg} / \mathrm{L}$, whereas the Institute of Water Modeling (2003) found ammonia in the range of 0.001$0.33 \mathrm{mg} / \mathrm{L}$ with an average figure of $0.043 \mathrm{mg} / \mathrm{L}$, which is comparatively lower than the amount recorded in the present study.

\section{Seasonal variations in nutrient levels}

During field measurements, most of the stations showed slightly higher concentrations of $\mathrm{NO}_{3}-\mathrm{N}$ during the monsoon period, whereas very few locations showed the occurrence of elevated amounts during either the postmonsoon or winter seasons. As Figure 6 shows, the concentration ranged between 0.06 and $0.40 \mathrm{mg} / \mathrm{L}$ during the post-monsoon period, whereas it was $0.06-0.46$ and $0.08-0.46 \mathrm{mg} / \mathrm{L}$ during the dry winter season and the monsoon season, respectively. Comparatively lower levels of nitrate were measured during winter except in Pashurtala and Pashurtala Canal, where higher concentrations were recorded in winter, during both high and low tide conditions.
Following the post-monsoon period, $\mathrm{PO}_{4}-\mathrm{P}$ concentrations were found to drop in the winter season and then to start rising again in the monsoon season at the Pashurtala, Pashurtala Canal and Kalagachhi stations, whereas at the Kalagachhi Canal, Nildumur and Arpangashia sites, phosphate values continued rising even after the post-monsoon period, and two maximum concentrations of 0.24 and $0.42 \mathrm{mg} / \mathrm{L}$ were recorded during winter observation (Figure 7). Postmonsoon, dry winter and monsoon field measurements showed phosphate contents in the range of 0.09-0.18, $0.05-0.42$, and $0.10-0.16 \mathrm{mg} / \mathrm{L}$, respectively, indicating that between-station variation was lowest during the monsoon period.

Table 4 Environmental quality standards (EQS) for water parameters in Bangladesh

\begin{tabular}{ll}
\hline Parameters & EQS limits \\
\hline $\mathrm{DO}$ & $5-6 \mathrm{mg} / \mathrm{L}$ \\
$\mathrm{pH}$ & $6.5-8.5$ \\
$\mathrm{NH}_{3}-\mathrm{N}$ & $0.5 \mathrm{mg} / \mathrm{L}$ \\
$\mathrm{NO}_{3}-\mathrm{N}$ & $10 \mathrm{mg} / \mathrm{L}$ \\
$\mathrm{PO}_{4}-\mathrm{P}$ & $6-10 \mathrm{mg} / \mathrm{L}$ \\
$\mathrm{SO}_{4}$ & $400 \mathrm{mg} / \mathrm{L}$ \\
\hline
\end{tabular}

(Source: DOE 1991). 
Sulphate concentrations showed a distinct pattern of seasonal fluctuation. With very few exceptions, higher $\mathrm{SO}_{4}$ values were found during monsoon, while lower levels were detected during the post-monsoon season. For the majority of the sampling stations, sulphate levels started rising during the dry winter period following the post-monsoon period, and this increasing trend continued over the monsoon season (Figure 8). Sulphate contents ranged from 58.71 to $86.14 \mathrm{mg} / \mathrm{L}, 68.68$ to $119.01 \mathrm{mg} / \mathrm{L}$ and 78.15 to $136.47 \mathrm{mg} / \mathrm{L}$ during post monsoon, dry winter and monsoon seasons, respectively.

Post-monsoon and dry seasons did not experience any considerable fluctuations in ammonia concentrations, while monsoon data indicated significantly higher values of ammonia at all the study points during both rising and falling tides (Figure 9). Seasonal fluctuations in ammonia ranged from 0.02 to $0.08 \mathrm{mg} / \mathrm{L}, 0.02$ to $0.04 \mathrm{mg} / \mathrm{L}$ and 0.26 to $0.38 \mathrm{mg} / \mathrm{L}$ during post-monsoon, dry winter, and monsoon seasons, respectively.

Study results revealed that, during monsoon season, the concentration of most of the nutrients increased at the majority of stations, there was a decreasing trend of DO and salinity, and an increasing tendency for temperature, EC and TDS. A study pertaining to seasonal variation in physicochemical properties was carried out by Kumar et al. (2009) at Tapi estuarine zone of India. It revealed that the estuarine zone was significantly influenced by freshwater input during monsoon and post-monsoon periods, and the concentration of all the nutrients and dissolved oxygen (DO) was relatively high during the monsoon, whereas salinity levels were at their lowest. Rahaman et al. (2013a) studied spatial variation and seasonality of nutrient dynamics in major RS of the Sundarbans estuarine mangrove ecosystem and concluded that water quality was significantly affected by freshwater input during monsoon. Rahman et al. (2013) who observed water quality in Rupsha-Passur RS concluded that the water quality parameters of the river were acceptable during rainy season; however, moderate to high values of these parameters were present in winter and summer seasons. The authors also highlighted that there is a pronounced variation in most of the water quality parameters with variation in season and geographical location. Adedokun et al. (2008) found that many physical parameters ( $\mathrm{pH}, \mathrm{BOD}, \mathrm{DO}, \mathrm{COD}, \mathrm{TDS}$, total hardness) and nutrient load-based parameters (phosphate, sulphate, nitrate and nitrite) were generally higher during the rainy season in a Nigerian RS.

\section{Tidal variations of nutrients}

The concentration of $\mathrm{NO}_{3}-\mathrm{N}$ was found to be inconsistent at different times in the tidal cycle. With respect to combined tidal and seasonal effects, $\mathrm{NO}_{3}-\mathrm{N}$ concentrations were found to vary in an independent manner.
During a falling tide, nitrate levels ranged from 0.04 to $0.40 \mathrm{mg} / \mathrm{L}$, whereas during a rising tide, the concentrations ranged from 0.05 to $0.46 \mathrm{mg} / \mathrm{L}$. Higher and lower levels of nitrates were found during both high and low tides (Figure 6).

Similarly to nitrate, no distinct tidal variation pattern was observed for $\mathrm{PO}_{4}-\mathrm{P}$ at the study sites. During high and low tides, phosphate levels ranged from 0.05 to $0.42 \mathrm{mg} / \mathrm{L}$ and 0.07 to $0.18 \mathrm{mg} / \mathrm{L}$, respectively. Kalagachhi Canal and Nildumur stations showed significantly higher concentrations of $\mathrm{PO}_{4}-\mathrm{P}$ during high tide than low tide (Figure 7).

Sulphate values did not show any significant trend with tidal variations. During the highest tides in the post-monsoon season, sulphate concentrations were just slightly higher than in low tide conditions, whereas during monsoon season, the sulphate content at low tide was higher than at high tide at Pashurtala Canal, Kalagachhi Canal and Nildumur. During winter, at Pashurtala, Pashurtala Canal, Kalagachhi Canal and Nildumur, sulphate concentrations were found to be higher when tidal levels were rising, whereas the fluctuation pattern was just the opposite at other stations (Figure 8). Kholpetua-Arpangashia RS showed high and low tidewater sulphate concentrations of 63.63125.36 and $58.71-136.47 \mathrm{mg} / \mathrm{L}$, respectively.

During the monsoon season sampling, $\mathrm{NH}_{3}-\mathrm{N}$ concentrations were slightly higher at high tide than at low tide, and this trend in tidal variation was observed at all the stations. In contrast to the results during monsoon and winter seasons, ammonia contents during the postmonsoon season at high tide were little ahead of low tide for maximum tidal cycles (Figure 9). Senthilkumar et al. (2008) conducted an experiment on seasonal and tidal dynamics of nutrients in a mangrove estuary along the southeast coast of India in a 24-h diurnal survey in both dry and wet seasons. They found that the distribution of nutrients is influenced by tidal cycle as indicated by changes in tidal height. Rahaman et al. (2013b), who made field observations in the Sundarbans intertidal mangrove forest to analyze spatial and temporal variations in phytoplankton abundance and species diversity, reported that spatial and temporal variations in water quality conditions of the RSs indicate the influence of various climatic and local forcing functions.

\section{Conclusions}

The present study summarizes the seasonal and tidal fluctuations in nutrient levels and various physicochemical parameters in the river waters of the Sundarbans mangrove estuary. The results indicate that the nutrients are significantly affected by seasonal changes and to some extent by variations in tidal height also. However, in most cases, water quality was not found to follow any 
distinct tidal fluctuation pattern. The highest concentrations for $\mathrm{PO}_{4}-\mathrm{P}, \mathrm{SO}_{4}$ and $\mathrm{NH}_{3}-\mathrm{N}$ and comparatively lower values for $\mathrm{DO}$ and salinity were observed during the monsoon season. $\mathrm{NO}_{3}-\mathrm{N}$ showed higher levels at most of the experimental sites during monsoon, whereas elevated concentrations were also observed at some sampling points during the post-monsoon and winter periods. The west part of the mangrove forest, which is characterized by higher salinity throughout the year than the other parts of the Sundarbans, showed extremely high ammonia levels during monsoon. As huge agricultural and aquaculture activities are conducted in the periphery of western Sundarbans, considerable amounts of washed-out inorganic fertilizers might contribute to this increased ammonia level during the rainy season. In comparison to other parts of the Sundarbans, however, the western region does not otherwise show alarming deterioration in water quality as the adjacent coastal land, although heavily used for farming, has yet to go through mass industrialization. However, increasing agriculture activities, shrimp farming and human settlement, uncontrolled deforestation, restricted fresh water supply from upstream due to the Farakka barrage, increasing river siltation, unscientific changes in land use, and climate change all still pose threats to the water quality of the river as well as to the whole mangrove ecosystem. It is hoped that the findings of the study will be useful in developing policies for mangrove ecosystem conservation and management in Bangladesh.

\section{Competing interests}

The authors declare that they have no competing interests.

\section{Authors' contributions}

SMBR: Research concept and design, field monitoring, data analysis and interpretation, drafting and revision of the manuscript, and final approval of the version to be published. LS: In-situ measurement and laboratory analysis, acquisition of data, data analysis, and initial set-up of the manuscript. MSR: Research design, in-situ measurement and laboratory analysis. AKG: Data analysis using Microsoft Office Excel, drafting of the research article. SKB: Insitu measurement and laboratory analysis. SMSS: In-situ measurement and laboratory analysis. KAH: Research concept and design. AFMH: Field monitoring. SSI: Data analysis using Microsoft Office Excel. All authors read and approved the final manuscript.

\footnotetext{
Acknowledgements

Ministry of Education, Government of the Peoples' Republic of Bangladesh provided the necessary financial support under the Grants for Advanced Research in Science to carry out the present study. The authors would like to acknowledge the support of the laboratory staff of the Fisheries and Marine Resource Technology Discipline and Environmental Science Discipline of Khulna University during sample analysis in the laboratory. Thanks are due to the graduate and undergraduate students for their generous cooperation during field observation, in-situ measurement and laboratory analysis. Support of the authorities of the Forest Department of Bangladesh are appreciated. The authors would like to thank two anonymous reviewers for their valuable comments and suggestions that helped improve the manuscript.
}

\section{Author details}

'Fisheries and Marine Resource Technology Discipline, Khulna University, Khulna 9208, Bangladesh. ${ }^{2}$ Chemistry Department, Comilla University, Comilla 3500 , Bangladesh.

Received: 13 May 2013 Accepted: 12 September 2013 Published: 2 October 2013

\section{References}

Adedokun OA, Adeyemo OK, Adeleye E, Yusuf RK (2008) Seasonal limnological variation and nutrient load of the river system in Ibadan metropolis, Nigeria. Eur J Sci Res 23(1):98-108

APHA (1992) Standard methods for the examination of water and wastewater, 18th edn. American Public Health Association, Washington DC

Badran M (2001) Dissolved oxygen, chlorophyll a and nutrient seasonal cycles in waters of the Gulf of Aqaba, Red Sea. Aquat Ecosyst Health Manage 4 (2):139-150

Coonley LS, Baker EB, Holland HD (1971) Iron in the Mullica River and the Great Bay, New Jersey. Chem Geo 7:51-63

DOE (1991) Environmental quality standards (EQS) for Bangladesh. Department of Environment (DOE), Government of Bangladesh, Bangladesh

Eyre BD, Twigg C (1997) Nutrient behaviour during post-flood recovery of the Richmond river estuary northern NSW, Australia. Estuar Coast Shelf Sci 44:311-326

Gobeil C, Sundby B, Silverberg N (1981) Factors influencing particulate matter geochemistry in the St. Lawrence turbidity maximum. Mar Chem 10:123-140

Hoq ME, Islam ML, Paul HK, Ahmed SU, Islam MN (2002) Decomposition and seasonal changes in nutrient constituents in mangrove litter of Sundarbans mangrove, Bangladesh. Ind J Mar Sci 31(2):130-135

Hoq ME, Wahab MA, Islam MN (2006) Hydrographic status of Sundarbans mangrove, Bangladesh with special reference to post-larvae and juveniles fish and shrimp abundance. Wetlands Ecol Manage 14:79-93

IWM (Institute of Water Modeling) (2003) Surface water modeling. The Sundarbans Biodiversity Conservation Project TA No. 3158-BAN. Final report, volume 1. IWM, Dhaka, Bangladesh

Katebi MNA (2001) Sundarbans and forestry. In: Haider R (ed) Cyclone '91: an environmental and perceptional study. BCAS, Dhaka, pp 79-100

Kumar JIN, George B, Kumar RN, Sajish PR, Viyol S (2009) Assessment of spatial and temporal fluctuations in water quality of a tropical permanent estuarine system - Tapi, west coast India. Appl Ecol Env Res 7(3):267-276

Mitra A, Mondal K, Banerjee K (2011) Spatial and tidal variations of physico chemical parameters in the lower Gangetic delta region, west Bengal, India. J Spat Hydro 11:52-69

Mukhopadhyay SK, Biswas HDTK, Jana TK (2006) Fluxes of nutrients from the tropical river Hooghly at the land-ocean boundary of Sundarbans, NE coast of Bay of Bengal, India. J Mar Syst 62:9-21

Nair KVK (1985) Impact of nuclear power station on the hydrobiological characteristics of Kalpakkam waters. Proceedings of the symposium on seawater quality demands, Bombay, India, pp 13.1-13.10

NEERI (1976) Baseline water quality studies in the Hooghly estuary. National Environmental Engineering Research Institute, Nagpur, India

Pliński M, Jóźwiak T (1999) Temperature and N:P ratio as factors causing blooms of blue-green algae in the Gulf of Gdańsk. Oceanologia 41(1):73-80

Rahaman SMB, Golder J, Rahaman MS, Hasanuzzaman AFM, Huq KA, Begum S, Islam SS, Bir J (2013a) Spatial and temporal variations in phytoplankton abundance and species diversity in the Sundarbans mangrove forest of Bangladesh. J Mar Sci Res Dev 3(2):1-9

Rahaman SMB, Sohag MSH, Ghosh AK, Biswas SM, Sarder L, Bir J, Siraj SMS (2013b) Spatial and temporal variation of total nitrogen and total phosphorus in major river systems of Sundarbans mangrove forest, Bangladesh. Int J Mar Sci 3(16):128-134

Rahman MM, Rahman TM, Rahaman MS, Rahman F, Ahmad JU, Shakera B, Halim MA (2013) Water quality of the world's largest mangrove forest. Can Chem Trans 1(2):141-156

Ramanathan AL, Subramanian V, Ramesh R, Chidambaram S, James A (1993) Environmental geochemistry of the Pichavaram mangrove ecosystem (tropical), southeast coast of India. Env Geol 37(3):223-233

Senthilkumar B, Purvaja R, Ramesh R (2008) Seasonal and tidal dynamics of nutrients and chlorophyll $a$ in a tropical mangrove estuary, southeast coast of India. Ind J Mar Sci 37(2):132-140 
Sholkovitz ER (1976) Flocculation of dissolved organic and inorganic matter during the mixing of river water and seawater. Geochim Cosmochim Acta 37:851-880

Tait RV (1981) Elements of marine ecology: an introductory course, 3rd edn. Butterworth-Heinemann, Oxford

Wahid SM, Mukand SB, Bhuiyan AR (2007) Hydrologic monitoring and analysis in the Sundarbans mangrove ecosystem, Bangladesh. J Hydrol 332:381-395

Weiss R (1970) The solubility of nitrogen, oxygen and argon in water and seawater. Deep Sea Res Oceanogr Abstracts 17(4):721-735

Yeats PA, Bewers JM (1982) Discharge of metals from St. Lawrence river. Can J Earth Sci 19:982-992

doi:10.1186/2192-1709-2-29

Cite this article as: Rahaman et al:: Nutrient dynamics in the Sundarbans mangrove estuarine system of Bangladesh under different weather and tidal cycles. Ecological Processes 2013 2:29.

\section{Submit your manuscript to a SpringerOpen ${ }^{\circ}$} journal and benefit from:

- Convenient online submission

- Rigorous peer review

- Immediate publication on acceptance

- Open access: articles freely available online

- High visibility within the field

- Retaining the copyright to your article

Submit your next manuscript at $>$ springeropen.com 